\title{
Erratum to: The association of health literacy with adherence in older adults, and its role in interventions: a systematic meta-review

Bas Geboers ${ }^{1 *}$, Julii S. Brainard ${ }^{2}$, Yoon K. Loke ${ }^{2}$, Carel J. M. Jansen ${ }^{3}$, Charlotte Salter ${ }^{2}$, Sijmen A. Reijneveld ${ }^{1}$ and Andrea F. de Winter ${ }^{1}$

After the publication of this article it was brought to our attention that the name of the last author, Andrea F. de Winter had been accidentally misspelt as Andrea F. deWinter in the original publication [1]. This has been updated in the article and corrected with this erratum.

\footnotetext{
Author details

'Department of Health Sciences, University Medical Center Groningen, University of Groningen, Antonius Deusinglaan 1, FA10, Groningen 9700 AD, The Netherlands. ${ }^{2}$ Norwich Medical School, Faculty of Medicine \& Health Sciences, University of East Anglia, Norwich, UK. ${ }^{3}$ Department of

Communication and Information Studies, Faculty of Arts, University of Groningen, Groningen, The Netherlands.
}

Received: 21 September 2015 Accepted: 1 October 2015

Published online: 26 October 2015

\section{Reference}

1. Bas G, Julii B, Yoon L, Carel J, Charlotte S, Sijmen R, et al. The association of health literacy with adherence in older adults, and its role in interventions: a systematic meta-review. BMC Public Health. 2015;15:903.

\footnotetext{
* Correspondence: b.j.m.geboers@umca.nl

1 Department of Health Sciences, University Medical Center Groningen, University of Groningen, Antonius Deusinglaan 1, FA10, Groningen 9700 AD, The Netherlands

Full list of author information is available at the end of the article

\section{Submit your next manuscript to BioMed Central} and take full advantage of:

- Convenient online submission

- Thorough peer review

- No space constraints or color figure charges

- Immediate publication on acceptance

- Inclusion in PubMed, CAS, Scopus and Google Scholar

- Research which is freely available for redistribution

Submit your manuscript at www.biomedcentral.com/submit 